УДК 621.575: 620.91: 662.997

\title{
Пошук енергоефективних режимів роботи систем отримання води 3 атмосферного повітря на базі абсорбційних водоаміачних термотранс- форматорів тепла і сонячних колекторів
}

\author{
С. О. Осадчук \\ ${ }^{1,2}$ Одеська національна академія харчових технологій, вул. Дворянська, 1/3, Одеса, 65082, Україна \\ $\triangle$ e-mail: ${ }^{1}$ osadchuk1980@gmail.com; ${ }^{2}$ titlov1959@gmail.com \\ ORCID: ${ }^{1}$ http://orcid.org/0000-0002-8955-2041; ${ }^{2}$ https://orcid.org/0000-0003-1908-5713
}

\begin{abstract}
В роботі показано, що система отримання води з атмосферного повітря з джерелом тепла від сонячних колекторів $i$ з абсорбиійним водоаміачним термотрансформатором тепла (ABTT), з підтискаючим бустер-компресором перед конденсатором, може бути пращездатною з джерелами тепла від $85{ }^{\circ} \mathrm{C}$. Порівняльний аналіз енергетичних витрат на стиснення пари робочого тіла в АВТT з підтискаючим бустер-компресором і в парокомпресорному термотрансформаторі тепла (ПКТТ) показав перевагу ABTT, як при експлуатації в помірному, так і тропічному кліматі. Проведено розрахунки максимальної енергоефективності ABTT, яка в розглянутому діапазоні параметрів досягається при тиску генерачії 1,0 МПа, і в умовах помірного клімату залежить від масової частки «міцного» водоаміачного розчину (ВАР) та температури випаровування. Найбільш енергоефективним є режим роботи $A B T T$ з температурою в випарнику $5{ }^{\circ} \mathrm{C}$. У иьому випадку має місце і мінімальна кратність циркуляиії ВАР, що знижує витрату робочого тіла $i$, відповідно, теплове навантаження генератора та спрошує рішення задачі охолодження абсорбера. Практично у всіх розглянутих кліматичних зонах з дефіџитом водних ресурсів процес отримання води з атмосферного повітря найбільш енерговитратний в зимовий період року, а найбільш енергоефективний - в літній. У літній період року питомі енерговитрати чисельно однакові при зміні кінцевої температури в процесі охолодження від 5 до $15{ }^{\circ} \mathrm{C}$. Це дозволить організувати енергозберігаючий процес роботи термотрансформаторів тепла різного типу за рахунок підвищення температури кипіння у випарнику. Розроблено варіант системи отримання води в транспортному виконанні, яка призначена для роботи в польових умовах в автономному режимі.
\end{abstract}

Ключові слова: Абсорбчійний водоаміачний термотрансформатор тепла; Водоаміачний розчин; Сонячні колектори; Система отримання води; Енергоефективність

doi: https://doi.org/10.15673/ret.v56i3-4.1951

(C) The Author(s) 2019. This article is an open access publication

This work is licensed under the Creative Commons Attribution 4.0 International License (CC BY) http://creativecommons.org/licenses/by/4.0/

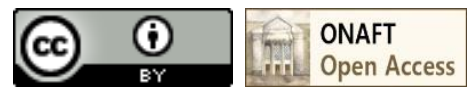

\section{1. Вступ}

Загальновідомо, що найціннішим ресурсом на планеті найближчим часом стане вода, а боротьба за водні ресурси в світі є одним з факторів в су- часних збройних конфліктах, і ця тенденція буде тільки зростати в осяжному майбутньому.

Для сприяння у вирішенні цієї проблеми, в грудні 2003 року Генеральна Асамблея Організації Об'єднаних Націй оголосила 2005-2015 роки Між- 
народним десятиріччям дій «Вода для життя». За даними ООН [1]:

1. Налічується більше 1 млрд. людей, які не мають стійкого доступу до чистої води. 2,4 млрд. людей - більше однієї третини населення світу - не мають доступу до належних засобів санітарії. Ця ситуація призводить до катастрофічних наслідків.

2. Щорічно понад 2,2 млн. чоловік, головним чином в країнах, що розвиваються, вмирають від хвороб, пов'язаних з низькою якістю води і незадовільними санітарно-гігієнічними умовами.

3. Щодня 6 тис. дітей помирають від хвороб, які можна запобігти шляхом підвищення якості води та поліпшення санітарно-гігієнічних умов.

4. Понад $70 \%$ всіх наявних ресурсів прісної води використовується в сільськогосподарських цілях. Однак в результаті неефективної роботи зрошувальних систем, існуючих, зокрема, в країнах, що розвиваються, $60 \%$ цієї води випаровується або повертається в річки і в підземні води.

5. 31960 р. обсяг води, яка забирається на цілі зрошення, збільшився більш ніж на $60 \%$.

6. В даний час більше $40 \%$ населення світу живе в районах, що зазнають середню або гостру нестачу води. Передбачається, що до 2025 р. приблизно дві третини населення світу - близько 5,5 млрд. людей - буде жити в районах, які стикаються $з$ нестачею води в таких масштабах.

7. Все більше число регіонів світу, особливо в Північній Африці, а також Західній і Південній Азії, стикається з проблемою дефіциту води.

У таких регіонах, як США, Китай і Індія, темпи споживання підземних вод перевищують темпи ïх поповнення і відбувається постійне зниження рівня грунтових вод.

Близько $70 \%$ поверхні земної кулі покрито водою, проте на 97,5 \% вона складається з солоної води. Решта $(2,5 \%)$ припадає на прісну воду, майже дві третини якої перебуває в замороженому стані в льодовикових шапках. Тим часом, основна частина прісної води знаходиться в 1 км шарі атмосфери. За даними роботи [2] середня абсолютна вологість біля земної поверхні становить $11 \mathrm{r} / \mathrm{m}^{3}$, а в тропічних регіонах вона доходить до $25 \mathrm{r}_{\mathrm{m}}{ }^{3} \mathrm{i}$ вище. Велика кількість країн тропічного поясу страждає від відсутності прісної води, хоча ії зміст в атмосфері досить значний.

Тому одним 3 найважливіших завдань $є$ розвиток технологій, що дозволяють виділяти воду 3 повітря, причому безпосередньо на місці, де вона необхідна.

\section{2. Аналіз сучасного стану розробок}

3 давніх часів прісну воду, в дуже обмежених кількостях, отримували шляхом збору сконденсованих крапель 3 повітря в результаті природного добового радіаційного охолодження земної поверхні (охолодження в нічний час пористих каменів 3 утворенням роси) [3]. При зниженні температури на $10-15{ }^{\circ} \mathrm{C} 3$ кожного кубічного метра можна виділити 10-14 г води. Для підвищення ефективності процесу конденсації пари води в цих умовах використовують інтенсифікуючі елементи - холодоакумулятори (щебінь), теплові труби, що забезпечують передачу тепла на значні відстані і систему сорбентів, які працюють в циклічному режимі «зарядки-розрядки» [4].

В наш час, основний обсяг ринку обладнання по виділенню води 3 повітря припадає на системи, які мають в своєму складі компресійну холодильну установку з електричним приводом, і гарантовано забезпечують температуру нижче точки роси. Для отримання 1 літра води потрібно затратити близько 1 кВт· год електроенергії, а в середньому 3 потоку повітря 1 кг/с виділити 10 г/с води. При холодильному коефіцієнті компресорної холодильної машини, що дорівнює 3, на виробництво 1 літра води буде витрачатися енергія приблизно $\sim 0,33$ кВт·год [5]. Разом $з$ тим застосування компресорних установок перспективно тільки для продуктивності до 3-4 літрів води на годину. При більш високій продуктивності відбувається суттєве зростання габаритів установки.

Незрівнянно більша, в порівнянні з компресорними аналогами, продуктивність систем отримання води $з$ атмосферного повітря може бути досягнута при адіабатному розширенні в турбодетандері повітряної холодильної машини. Такі машини успішно застосовуються в космічній техніці при організації запуску літальних апаратів [6].

Однак, в світі налічується чимало місць, а це країни Африки, Південно-Східної Азії, Південної Америки, де крім проблем з водою $є$ проблеми і 3 електроенергією, та й враховуючми глобальні проблеми з виснаженням нафтових і газових ресурсів планети - витрата електроенергії на рішення цієї проблеми стає проблематичною. Ці проблеми характерні і для південного регіону України [7].

У зв'язку з цим розробники систем отримання води 3 атмосферного повітря приділяють значну увагу тепловикористовуючим трансформаторам тепла, джерелом тепла в яких $є$ сонячна енергія. 
Одним 3 перспективних напрямків $є$ можливість використання існуючої інфраструктури сонячних нагрівачів води, сумарний обсяг площ колекторів

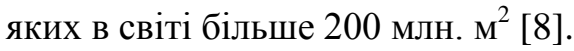

3 усіх можливих типів тепловикористовуючих трансформаторів тепла розробники зупиняють свій вибір на сорбційних схемах - 3 твердим (адсорбційний тип) [9-10] і рідким (абсорбційний тип) [11-16] поглиначами.

До недоліків сучасних адсорбційних схем [9-10] можна віднести їх прив'язку до рідинних систем охолодження теплорозсіювальних елементів (конденсатора і адсорбера), які припускають наявність градирні та витрати води на випарне охолодження. Вочевидь, що це робить їх застосування в посушливих регіонах, де спостерігається дефіцит води, недоцільним.

У той же час серед абсорбційних схем можна виділити схеми 3 водоаміачним розчином (ВАР) в якості робочого тіла $[14,15]$, які досить просто реалізуються при повітряному відводі тепла від теплорозсіювальних елементів, зокрема, в безнасосних схемах з вирівнюючим інертним газом [17, 18$]$.

Проте, абсорбційні водоаміачні трансформатори тепла (АВТТ) 3 повітряним охолодженням теплорозсіювальних елементів в більшості випадків не можуть бути безпосередньо використані в системах отримання води 3 атмосферного повітря при роботі з сонячними колекторами. Це пов'язано 3 тим, що в даний час основний парк сонячних колекторів становлять конструкції 3 водою в якості теплоносія [8]. Практична температура нагріву в таких системах не перевищує $100{ }^{\circ} \mathrm{C}$, а цього недостатньо для повноцінної реалізації циклу АВТТ навіть в зоні помірного клімату, як для насосної схеми (оптимальний робочий діапазон 120-140 ${ }^{\circ} \mathrm{C}$ ), так і для безнасосної (оптимальний робочий діапазон 150-170 ${ }^{\circ} \mathrm{C}$ ) [19]. Підвищений рівень температур в безнасосній схемі пов'язаний 3 наявністю інертного вирівнюючого газу (традиційно - водню), який дозволяє позбавитися від перекачувальних елементів конструкции [20].

Необхідно відзначити і той факт, що робочим тілом АВТТ насосного і безнасосного типу слугує природна робоча речовина - ВАР, що не виявляє несприятливого техногенного впливу на екосистему планети [21]. До того ж аміак дозволяє розширити сферу застосування АВТТ в частині зниження температури холодного джерела нижче $0{ }^{\circ} \mathrm{C}$, наприклад, для вирішення кондиціювання повітря або низькотемпературного зберігання хар- чових продуктів і сировини.

Таким чином, дослідження і розробки абсорбційних водоаміачних трансформаторів тепла 3 сонячними водяними колекторами для систем отримання води 3 атмосферного повітря в частині підвищення їх енергетичної ефективності і розширення їх сфери застосування можна вважати актуальними.

\section{3. Аналіз енергоефективних режимів аб- сорбційних термотрансформаторів на базі сонячних колекторів}

В якості базового варіанту візьмемо оригінальну схему установки отримання води 3 атмосферного повітря (рис.1) [22], яка містить систему сонячних колекторів 1 , із замкнутим циркуляційним контуром 2, заповненим рідким теплоносієм, і теплообмінником 3. Циркуляція теплоносія по контуру 2 і теплообміннику 3 здійснюється за допомогою насоса 4.

До складу установки також входить АВТТ, який містить: генератор 5; бустер-компресор 6; повітряний конденсатор 7; дросельний вентиль холодильного агента 8; випарник 9; абсорбер 10; насос «міцного» розчину 11 ; дросельний вентиль 12, теплообмінник «міцного» і «слабкого» ВАР 13.

Випарник 9 i абсорбер 10 встановлені послідовно в спеціальному повітряному каналі 14 таким чином, щоб повітряний потік за допомогою вентилятора 15 надходив спочатку на випарник 9, а потім на абсорбер 10. Нижня частина випарника 9 пов'язана з ємністю для збору конденсату 16.

Охолодження конденсатора 7 здійснюється окремим вентилятором 17. У внутрішній порожнині генератора 5 встановлені канальні теплообмінники 3 циркуляційного контуру 2.

Робочим тілом АВТТ $є$ ВАР $з$ аміаком в якості холодильного агента, а водою - в якості поглинача пари аміаку (абсорбенту).

Система отримання води 3 атмосферного повітря 3 АВТТ і сонячними колекторами працює наступним чином.

У початковий момент після заправки АВТТ все робоче тіло знаходиться переважно в генераторі 5. При нагріванні сонячним тепловим випромінюванням колектора 1 теплоносій в ньому нагрівається, і в гарячому стані по контуру 2 насосом 4 прокачується через теплообмінник 4 через внутрішню порожнину генератора 5. 


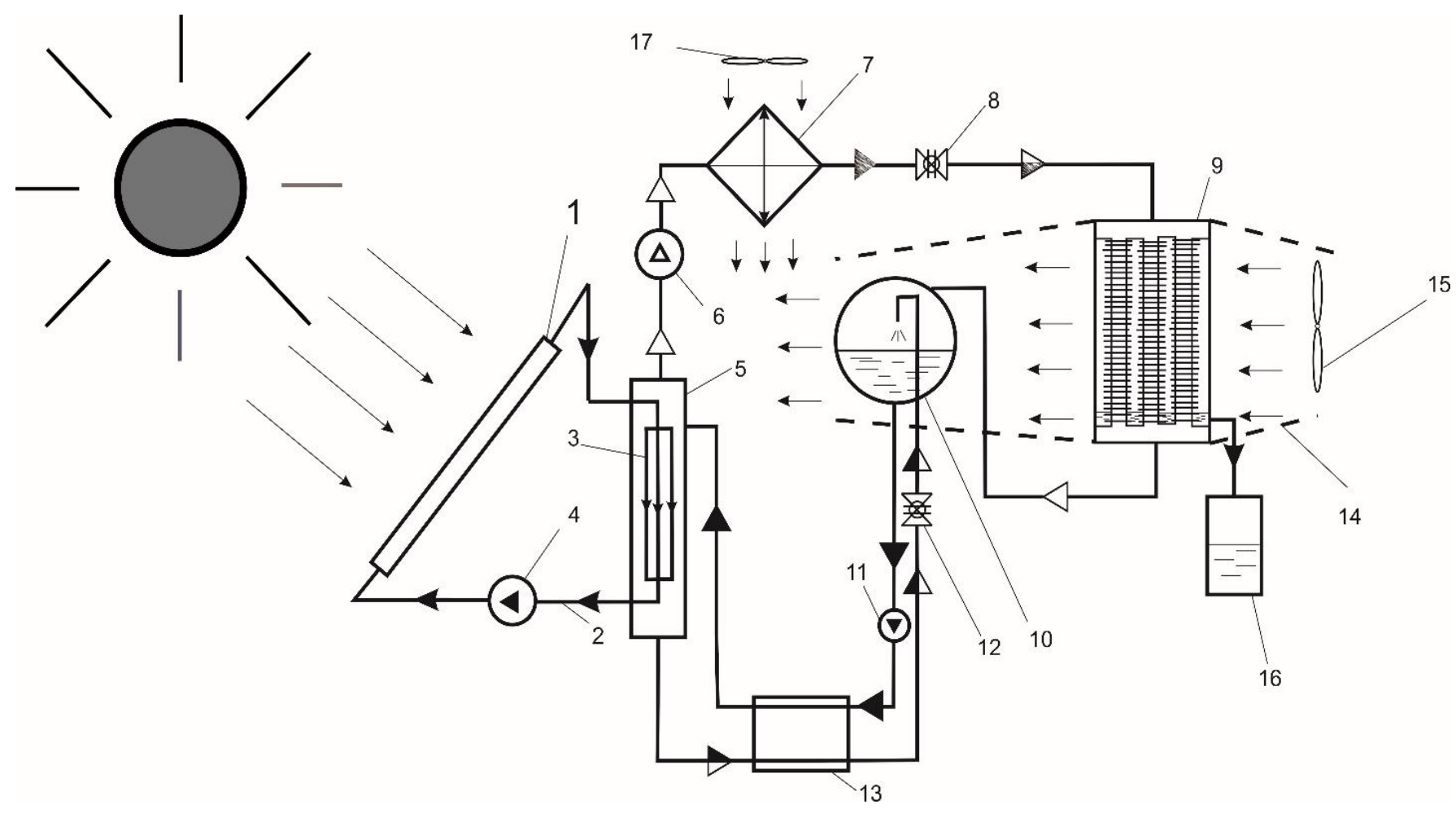

Рисунок 1 - Схема АВТТ з підтискаючим бустер-компресором:

1 -система сонячних колекторів; 2 - ичикулячійний контур; 3 - теплообмінник; 4 - циркуляційний насос; 5 -генератор; 6 - бустер-компресор; 7 - конденсатор пари аміаку; 8 -дросель рідкого аміаку;

9 - випарник; 10 -абсорбер; 11 - насос мічного розчину; 12 - дросель слабкого розчину;

13 - теплообмінник розчинів; 14 - повітряний канал; 15, 17 -вентилятор; 16 -збірник конденсату

3 водоаміачного розчину, що заповнює генератор 5, при тепловій взаємодії з теплообмінником 4 при тиску $P_{h}$ починає випаровуватися легкокиплячий компонент - аміак. Пар аміаку піднімається у верхню частину генератора 5, а збіднений аміаком розчин - «слабкий» розчин - опускається в нижню частину генератора 5 i проходить далі в абсорбер 10.

У генераторі 5 підтримується тиск $P_{h}$ вище, ніж в абсорбері $10 P_{a}$, тому «слабкий» розчин при русі до абсорберу проходить через дросель 12.

3 верхньої частини генератора 5 пар відкачується бустер-компресором 6 і 3 підвищеним тиском $P_{k}$ направляється в конденсатор 7, де тиск знижується з відведенням теплоти фазового переходу за допомогою вентилятора 17.

Рідкий аміак дроселюється у вентилі 83 падінням тиску з $P_{k}$ до $P_{a}$ і надходить у випарник 9. Випарник 9 по паровому трубопроводу сполучається 3 абсорбером 10 і має знижений, в порівнянні з генератором і конденсатором тиск:

$$
P_{a}<P_{h}<P_{k}
$$

При низькотемпературному кипінні аміаку в випарнику 9 на його стінках підтримується температура нижче температури точки роси атмосферного повітря в перехідні і теплі періоди року.

Вентилятор 15 направляє повітря на поверхню випарника, де частина вологи конденсується i стікає в ємність 16.

Пар аміаку, що виходить з випарника 9, надходить в абсорбер 10, де поглинається «слабким» BAP.

3 абсорбера 10 насичений аміаком «міцний» ВАР за допомогою циркуляційного насоса 11 долає перепад тисків $\Delta P=P_{h}-P_{a}$ і надходить в генератор 1 і цикл холодильної машини повторюється.

У запропонованій схемі передбачено повітряне охолодження теплорозсіювальних елементів, так як робота АВТТ планується в умовах дефіциту водних ресурсів 
За допомогою наведеного вище алгоритму було проведено аналіз циклів АВТТ з підтискаючим бустер-компресором перед конденсатором.

При аналізі особливий інтерес представляє своєрідний «модифікований холодильний коефіцієнт» циклу АВТТ $\left(\eta_{M}\right)$, який являє собою відношення отриманого корисного ефекту (штучного холоду $Q_{0}$ ) до витраченої в циркуляційному насосі $12 L_{\text {pump }}$ і бустер-компресорі $6 N_{B C}$ електричної потужності [23].

$$
\eta_{M}=\frac{Q_{0}}{N_{B C}+L_{\text {pump }}} .
$$

3 урахуванням того, що теплова енергія гріючого джерела надходить до генератора АВТТ від сонячних колекторів, iї, як би отриману даром, ми не враховували.

При аналізі енергетичних характеристик ABTT $з$ бустер-компресором в складі системи отримання повітря були розглянуті температури:

a) в випарнику: $-5{ }^{\circ} \mathrm{C} ; 0{ }^{\circ} \mathrm{C} ; 5{ }^{\circ} \mathrm{C}$;

б) максимальна в генераторі: $80{ }^{\circ} \mathrm{C}$; $90{ }^{\circ} \mathrm{C}$; $100^{\circ} \mathrm{C}$;

в) зовнішнього (атмосферного) повітря: $32{ }^{\circ} \mathrm{C}$; $43{ }^{\circ} \mathrm{C}$.

Розрахунки виконані для продуктивності випарника АВТT 1000 Вт.

Результати розрахунків наведені на рис. 2-5.

По-перше, було показано, що чисельні значення електричної потужності не перевищували 3 Вт, а в середньому лежали в діапазоні $1 . . .2$ Вт.

Питома потужність циркуляційного насоса:

$$
l_{\text {pump }}=\mathrm{v}^{\prime} \cdot f \cdot\left(P_{k}-P_{0}\right),
$$

а потужність:

$$
L_{\text {pump }}=l_{\text {pump }} \cdot D .
$$

Вплив максимальної температури в генераторі АВТT на електричну потужність циркуляційного насоса при різних тисках і температурах випаровування наведено на рис. 2 .

Аналіз рис. 2 показує, що з підвищенням температури в випарнику від мінус $5^{\circ} \mathrm{C}$ до $5^{\circ} \mathrm{C}$ у всіх випадках знижується і електрична потужність циркуляційного насоса.

Вплив же температури в генераторі на електричну потужність насоса неоднозначно: мають місце як монотонне зниження і зростання, а також і локальні максимуми.

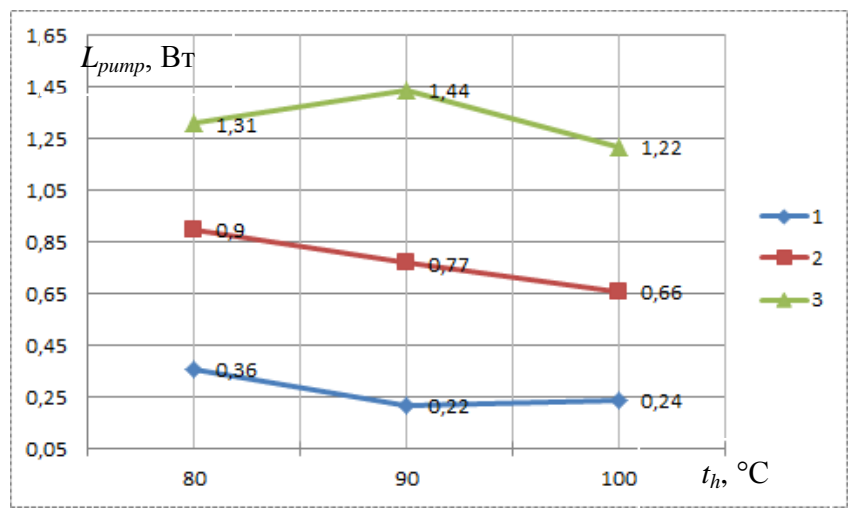

a)

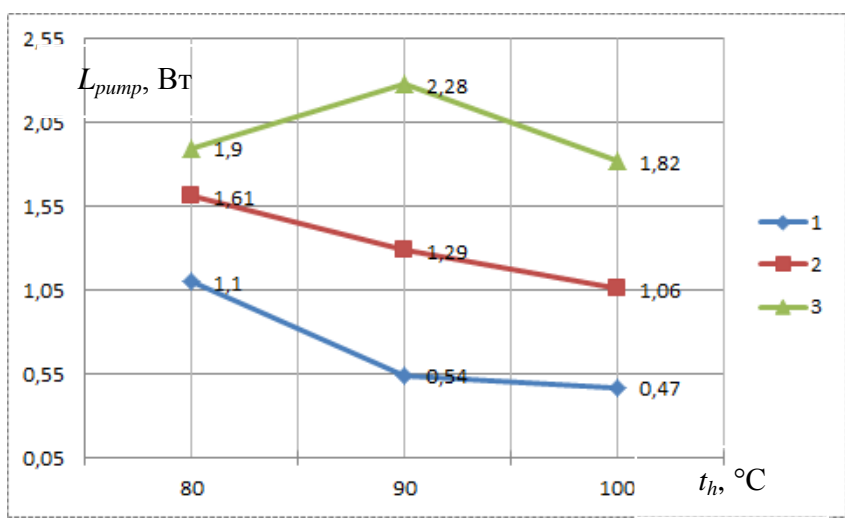

б)

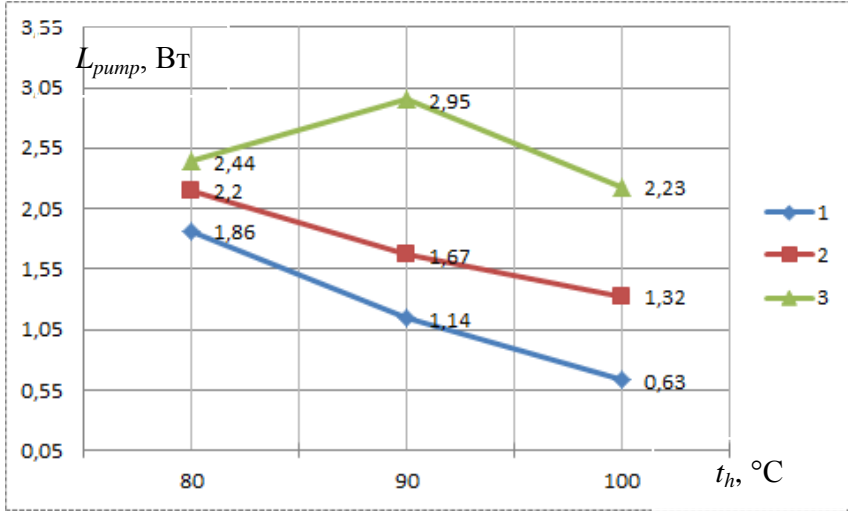

B)

Рисунок 2 - Вплив максимальної температури в генераторі АВТT на електричну потужність циркуляиійного насоса $\left(L_{\text {ритр }}\right)$ при температурі навколишнього середовища $32{ }^{\circ} \mathrm{C}$ і при температурах випаровування: а) $-5{ }^{\circ} \mathrm{C}$; б) $0{ }^{\circ} \mathrm{C}$; в) $5{ }^{\circ} \mathrm{C} \mathrm{ma} \mathrm{при}$ різних тисках: $1-1,0 ; 2-0,8 ; 3-0,6$ МПа

На рис.3 наведено співвідношення між теоретичними потужностями стиснення в компресорі парокомпресорного трансформатора тепла (ПКТТ) і бустер-компресорі в складі АВТТ при роботі в різних кліматичних умовах експлуатації. 


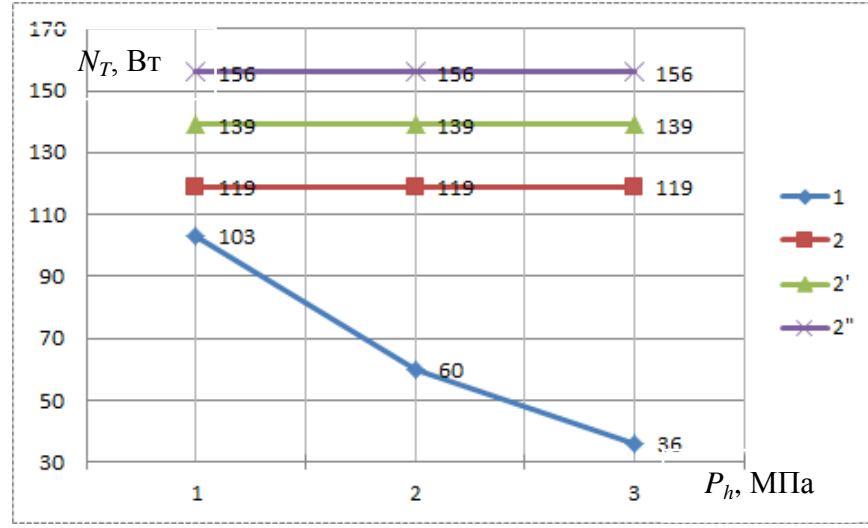

a)

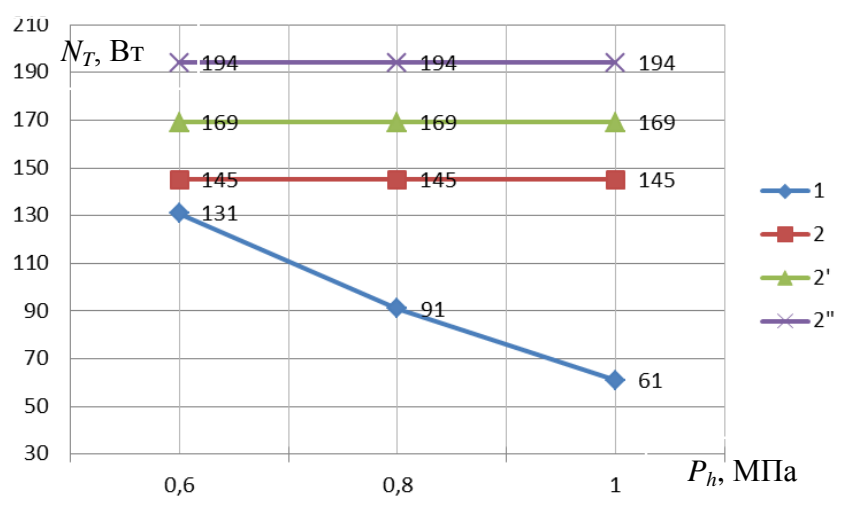

б)

Рисунок 3 - Вплив тиску в генераторі АВТT $i$ температури випаровування на теоретичну потужність стиснення в компресорі ПКТТ $i$ бустер-компресорі при роботі в різних кліматичних умовах експлуатайї: а) $32{ }^{\circ} \mathrm{C}$; б) $43{ }^{\circ} \mathrm{C}$; 1 -бустер-компресор; 2, 2', 2" - компресор ПКТТ; температури кипіння у випарнику ПКТТ:

2, 2', $2^{\prime \prime}-5{ }^{\circ} \mathrm{C} ; 0^{\circ} \mathrm{C} ;-5^{\circ} \mathrm{C}$, відповідно

$\mathrm{У}$ всіх розглянутих типових кліматичних умовах $\left(t_{W}=32{ }^{\circ} \mathrm{C}-\right.$ помірний клімат; $t_{W}=43{ }^{\circ} \mathrm{C}-$ тропічний клімат) при високому тиску в генераторі АВТТ знижувалася і теоретична потужність стиснення бустер-компресора, що вочевидь і пояснюється зниженням перепаду тиску між генератором і конденсатором.

В результаті розрахунку в практичному діапазоні параметрів було визначено енергоефективний режим для бустер-компресора АВТТ.

Для експлуатації систем в помірному кліматі це: тиск кипіння в генераторі 1,0 МПа і температура $80^{\circ} \mathrm{C}$.

Для умов роботи випарника при температурі $5{ }^{\circ} \mathrm{C}$ зниження електричної потужності в системах AВTT 3 бустер-компресором, в порівнянні 3 ПКТТ, в 3,3 рази - при експлуатації в помірному кліматі і 2,4 рази - в тропічному кліматі.
Термодинамічні параметри міцного ВАР при температурі $t_{W}=32{ }^{\circ} \mathrm{C}$ в залежності від температури в випарнику наведені в таблиці 1.

Таблиця 1 - Термодинамічні параметри міцуного BAP при температурі $t_{W}=32{ }^{\circ} \mathrm{C}$ в залежності від температури в випарнику

\begin{tabular}{|l|c|c|c|c|}
\hline Температура в випарнику & $-5{ }^{\circ} \mathrm{C}$ & $0{ }^{\circ} \mathrm{C}$ & $5{ }^{\circ} \mathrm{C}$ \\
\hline $\begin{array}{l}\text { Масова частка аміаку в } \\
\text { «міцному» ВАР }\end{array}$ & 0,48 & 0,51 & 0,57 \\
\hline Кратність циркуляції ВАР & 3,67 & 3,14 & 2,44 \\
\hline
\end{tabular}

*Примітка: для всіх випадків масова частка аміаку в «слабкому» ВАР визначається температурою абсорбції і становить 0,30 .

Аналіз результатів, наведених у табл. 1, показує, що найбільш енергоефективним $є$ режим 3 температурою в випарнику $5{ }^{\circ} \mathrm{C}$. У цьому випадку має місце і мінімальна кратність циркуляції ВАР, що знижує витрату робочого тіла i, відповідно, теплове навантаження генератора та спрощує рішення задачі охолодження абсорбера.

На рис.4 наведено залежності величини зони дегазації від температури випарника і тиску в генераторі. Розрахунки наведені для умов помірного клімату $\left(t_{W}=32{ }^{\circ} \mathrm{C}\right)$.

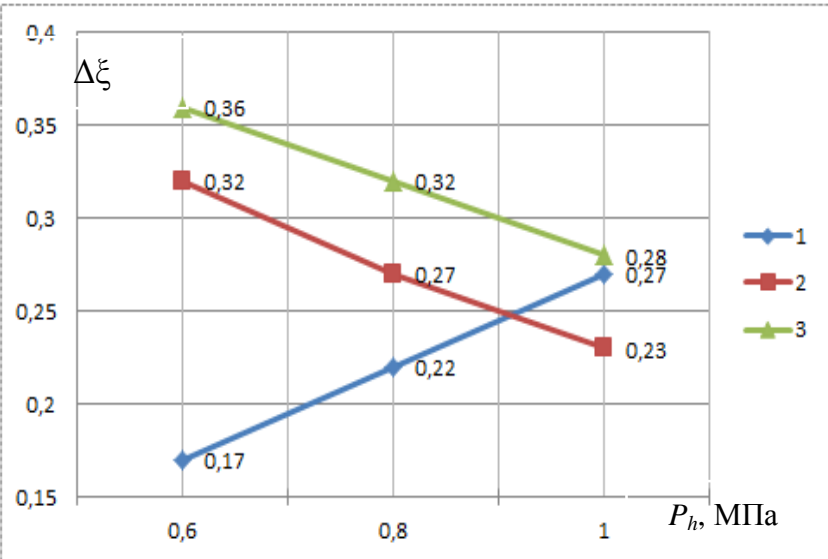

a)

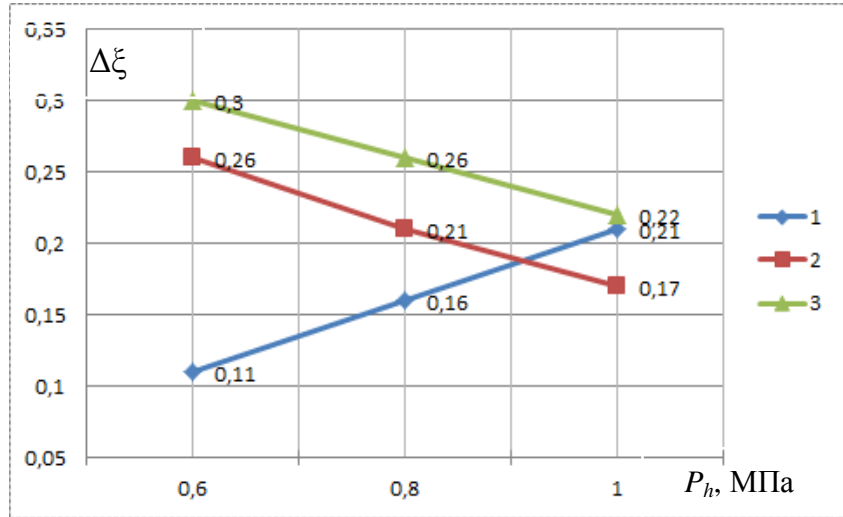

б) 


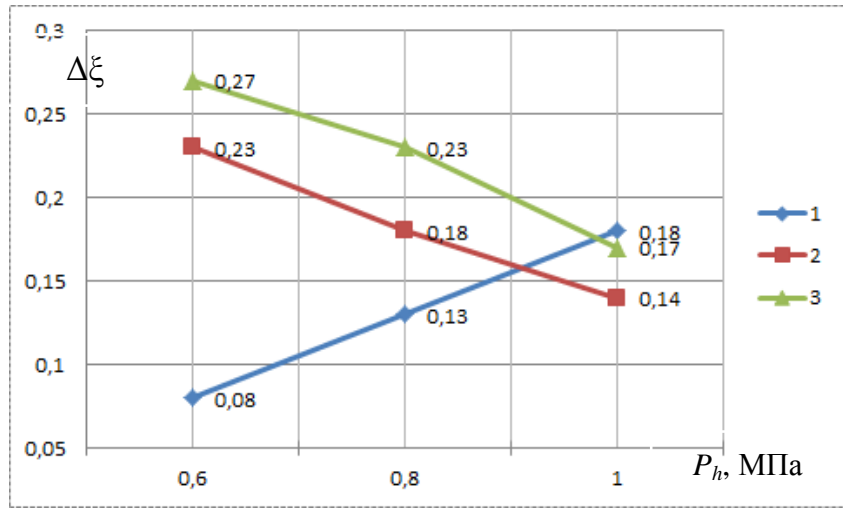

B)

Рисунок 4 - Залежність величини зони дегазації

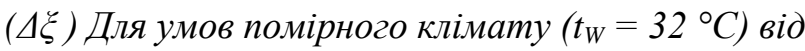
тиску в генераторі $\left(P_{h}\right)$ і температури випаровування: $1-80{ }^{\circ} \mathrm{C} ; 2-90^{\circ} \mathrm{C} ; 3-100^{\circ} \mathrm{C}$

Аналіз цих залежностей показує, що для інженерних рішень при тиску в генераторі 1,0 МПа відмінність між чисельними значеннями зони дегазації несуттєва. Так, для температури в випарнику $t_{0}=-5{ }^{\circ} \mathrm{C}$ зона дегазації складе $\Delta \xi=0,14 \ldots 0,18$, при $t_{0}=0{ }^{\circ} \mathrm{C}-\Delta \xi=0,17 \ldots 0,22$, при $t_{0}=5{ }^{\circ} \mathrm{C}-$ $\Delta \xi=0,23 \ldots 0,28$.

\section{4. Аналіз кліматичних особливостей регі- онів переважного застосуванням систем отримання води 3 атмосферного повітря}

На енергетичну ефективність термотрансформаторів тепла і компресорного і абсорбційного типів однаковим чином впливають температури об'єкта охолодження і навколишнього середовища $[24,25]$.

3 ростом температури навколишнього середовища i, відповідно, 3 підвищенням температури конденсації робочого тіла енергетична ефективність термотрансформаторів тепла знижується.

I навпаки, з ростом температури об'єкта охолодження i, відповідно, з підвищенням температури кипіння робочого тіла енергетична ефективність термотрансформаторів тепла підвищується.

Для зниження температури конденсації робочого тіла запропоновані цікаві рішення, пов'язані з використанням нічного радіаційного випромінювання для запасу природного холоду [26, 27]. При цьому ефект зниження температури до $5{ }^{\circ} \mathrm{C}$ досягався як в регіоні 3 континентальним [26], так і 3 тропічним кліматом [27].

Вочевидь, що для підвищення продуктивності систем отримання води 3 атмосферного повітря по конденсату-воді температура кипіння робочого тіла повинна бути якомога менше, але не нижче $0{ }^{\circ} \mathrm{C}$ для запобігання утворення інею на випарнику.

У той же час, в сучасних літературних джерелах немає певних рекомендацій по кінцевим температурам охолодження атмосферного повітря у випарниках термотрансформаторів тепла.

Мета дослідження - розробити рекомендації для розробників систем отримання води 3 атмосферного повітря за кінцевими температурами охолодження атмосферного повітря в термотрансформаторах тепла на основі термодинамічного аналізу тепловологісних процесів.

Для аналізу кліматичних особливостей були обрані типові регіони планети з проблемними водними ресурсами і з одночасною високою сонячною інсоляцією. Це міста Північної Африки і Близького Сходу: Алжир (Алжир); Дамаск (Сирія); Каїр (Сгипет); Тель-Авів (Ізраїль).

Наявність інтенсивного сонячного випромінювання дозволяє включати в схеми систем отримання води 3 атмосферного повітря тепловикористовуючі АВТT і мінімізувати витрати електричної енергії для штучного охолодження [22].

Статистичні дані про погодні умови в цих місцевостях були взяті з відкритих інтернет-ресурсів [28]. Для кожної пори року (літо, осінь, зима, весна) визначалися середня, максимальна і мінімальна температури і відповідна відносна вологість ( $\varphi)$.

Проводився розрахунок вмісту вологи атмосферного повітря через парціальний тиск насиченої водяної пари

$$
d=616 \frac{p}{10^{5}-p},
$$

де $p$ - парціальний тиск водяної пари в атмосферному повітрі, Па;

Для визначення парціального тиску водяної пари була виконана апроксимація табличних даних [29] і отримано наступне співвідношення

$$
p=a+b t+c t^{2}+d t^{3}+e t^{4}+f t^{5}, \Pi a
$$

де $a=611,366 ; b=44,427 ; c=1,423 ; d=0,027$; $e=0,0003 ; f=2,765 \cdot 10^{-6} ; t-$ температура, ${ }^{\circ} \mathrm{C}$.

Визначалася питома ентальпія атмосферного повітря 
$i=1,006 \cdot t+(2502,7+1,844 t) \frac{d}{1000}$, кДж/кг

Проводився розрахунок тепловологісного процесу політропного охолодження атмосферного повітря для трьох випадків кінцевих температур насичення $5{ }^{\circ} \mathrm{C}, 10^{\circ} \mathrm{C}, 15^{\circ} \mathrm{C}$.

Для визначення енергоефективності тепловологісних процесів охолодження і осушення використовувався комплекс $(\Delta i / \Delta d)$, який являє собою кутовий коефіцієнт (промінь процесу, тепловологісне відношення).

Для нашої задачі отримання води з атмосферного повітря цей комплекс характеризує енергетичну ефективність процесу, тобто кількість тепла, яку необхідно відвести від потоку атмосферного повітря, щоб отримати 1 кг конденсату-води.

Вочевидь, що чим чисельно менше цей комплекс, тим енергоефективніше тепловологісний процес отримання води 3 атмосферного повітря.

У табл. 2 наведені параметри атмосферного повітря (питома ентальпія $i_{t 0}$ i вологовміст $d_{t 0}$ ) при повному насиченні $(\varphi=100 \%)$ і кінцевій температурі $t_{0}$.

Таблиця 2 - Параметри атмосферного повітря при кінщевій температурі

\begin{tabular}{|c|c|c|}
\hline$t_{0},{ }^{\circ} \mathrm{C}$ & $i_{t 0}, \mathrm{\kappa Д} ж / \kappa \Gamma ~$ & $d_{t 0}, \Gamma / \kappa \Gamma$ \\
\hline 5 & 18,79 & 5,74 \\
\hline 10 & 29,58 & 7,73 \\
\hline 15 & 42,44 & 10,8 \\
\hline
\end{tabular}

Для більшої інформативності процесу аналізу результатів розрахунку були побудовані залежності тепловологісних параметрів для різних міст (рис. 5).

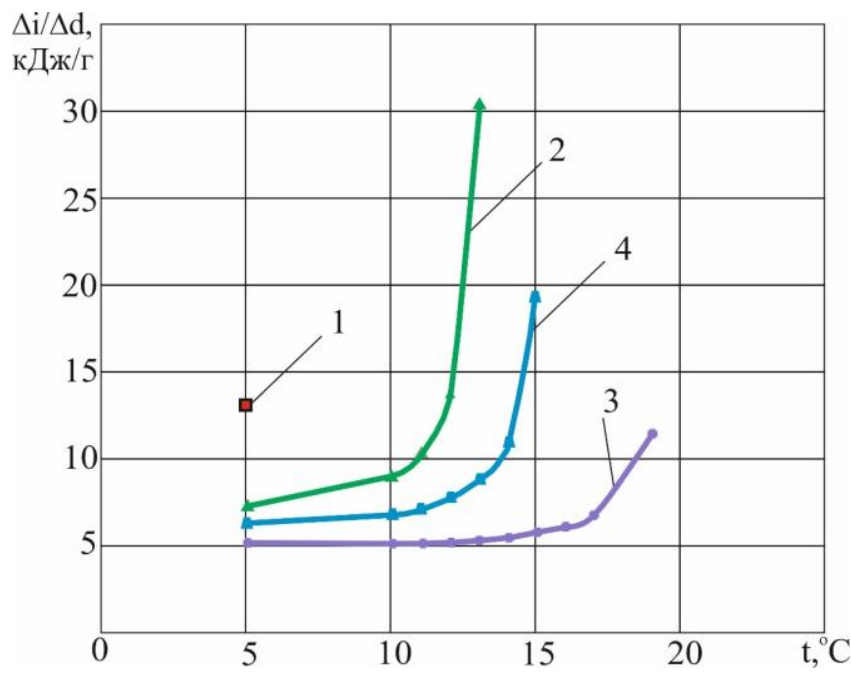

a)

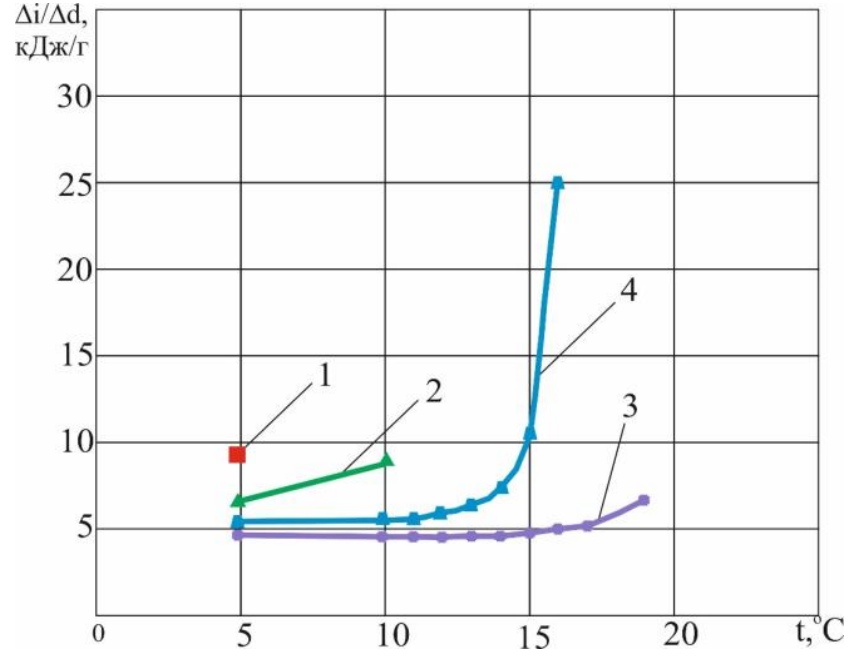

б)

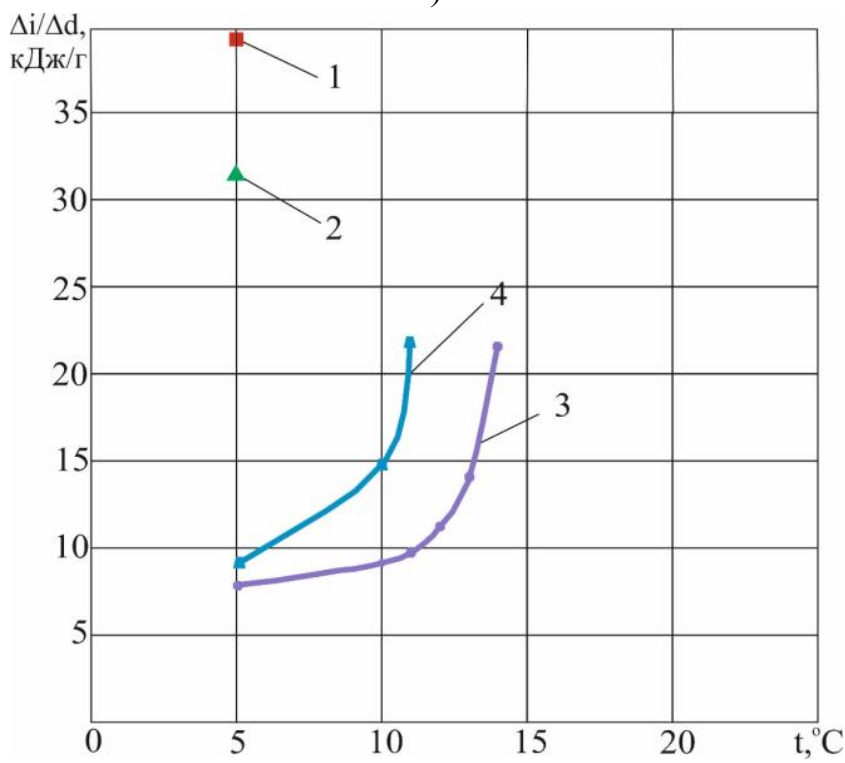

в)

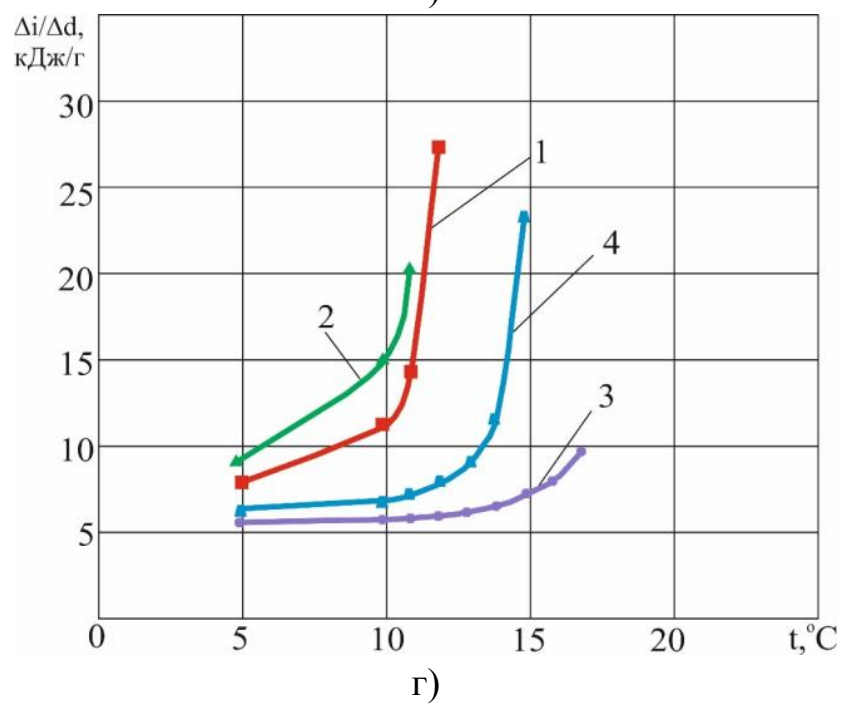

Рисунок 5 - Залежності тепловологісних параметрів атмосферного повітря в прочесі його охолодження від мінімальної температури охолодження для різних міст світу: $а$ - Тель-Авів; б - Алжир; в - Дамаск; г-Каїр; 1 -зима; 2 -весна; 3 -літо; 4 -осінь 
Для визначення тенденцій зміни ходу розрахункових залежностей кінцеві температури охолодження повітря у випарниках АВТТ були продовжені в бік збільшення.

У підсумку, отримані розрахункові залежності показали, що робота систем отримання води 3 атмосферного повітря в зимовий і весняний період в більшості випадків вимагає максимального охолодження атмосферного повітря (до $5-10{ }^{\circ} \mathrm{C}$ ), та й самі процеси максимально енерговитратні.

Розрахунки показали, що найбільш енергоефективні режими роботи систем отримання води 3 атмосферного повітря мають місце в літній період. При цьому для Тель-Авіву, Алжиру і Каїра достатньо охолоджувати атмосферне повітря до $17-18{ }^{\circ} \mathrm{C}$ і обійтися без додаткових витрат на більш глибоке охолодження.

Слід зазначити, що дане дослідження має на меті звернення уваги фахівців в області енергомашинобудування на особливості клімату, в якому передбачається експлуатація розробок. І при цьо- му враховувати сезонну зміну тепловологісних параметрів атмосферного повітря.

Найбільшою мірою це відноситься до систем отримання води, що працюють 3 атмосферним повітрям, які зазнають не тільки сезонні, а й добові зміни тепловологісних параметрів.

Так, наприклад, облік сезонної зміни тепловологісних параметрів атмосферного повітря протягом календарного року при управлінні ПКТТ дозволив знизити енерговитрати при експлуатації до $40 \%$ [15].

Для АВТТ облік кліматичних змін умов експлуатації дозволив підвищити енергоефективність до $35 \%$ [16].

\section{5. Системи отримання води транспортного виконання}

Принципова схема конструкції наведена на рис.6.
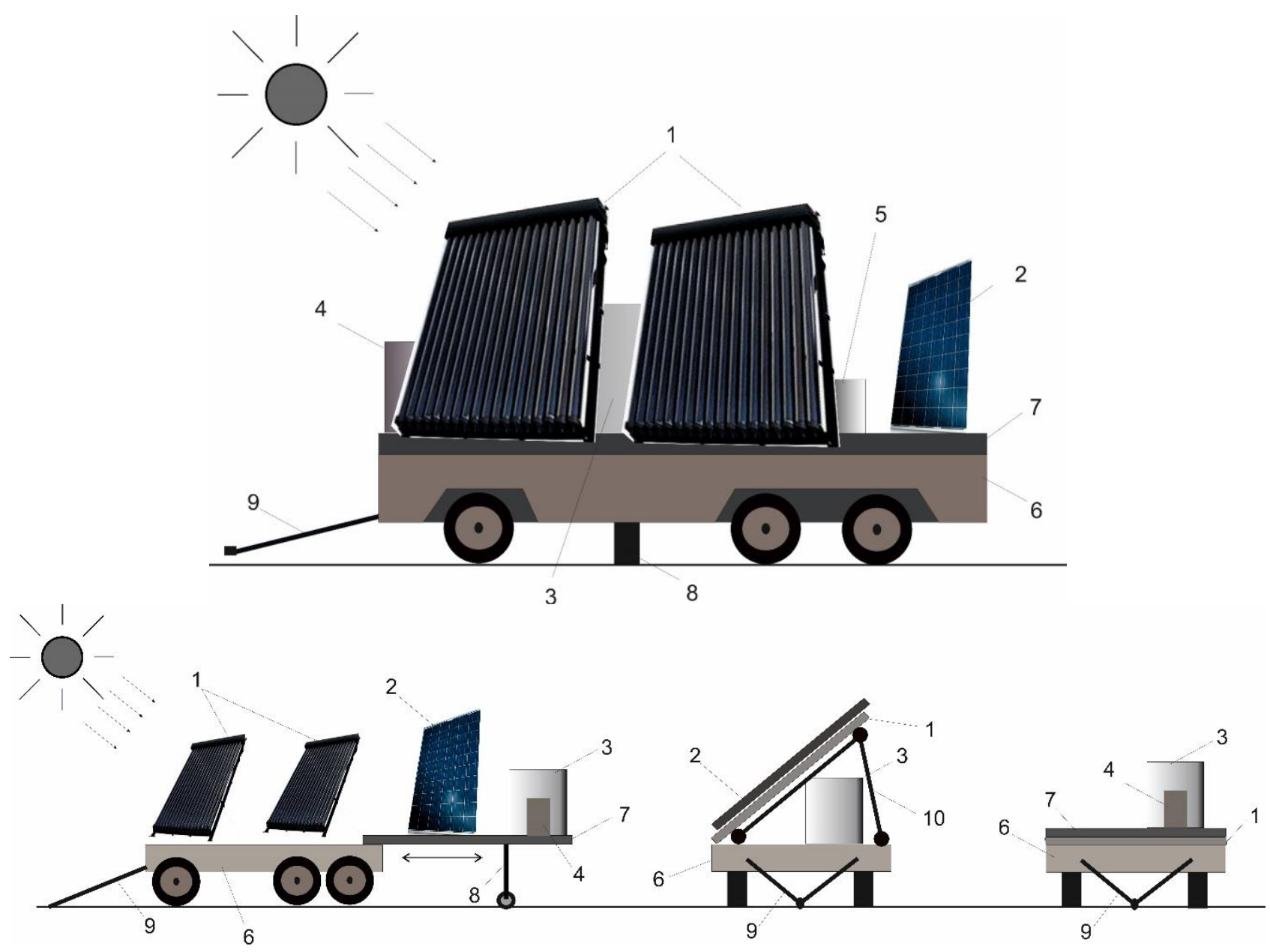

Рисунок 6 - Принципова схема конструкиії системи отримання води з атмосферного повітря в транспортному виконанні: а) загальний вигляд; б) функиіональні можливості; 1 - сонячні колектори; 2 - сонячні батареї; 3 - АВTT; 4 - система управління; 5 - перетворювач постійного струму в змінний; 6-платформа; 7 - висувна рама; 8-висувна опора; 9 - буксирувальна рама 
Система отримання води 3 атмосферного повітря на базі АВТT розташована на транспортній платформі 6 з можливістю буксирування 9 і компактної збірки.

До складу системи отримання води 3 атмосферного повітря входить АВТТ 3 з системою управління 4, системою підведення теплової енергії на базі сонячних колекторів 1 і система електрозабезпечення на базі сонячних батарей 2 .

Сонячні батареї 2 підтримують роботу системи управління, плавність ходу насосу, бустер-компресора АВТТ при відсутності централізованих джерел електричної енергії.

При русі платформи АВТТ знаходиться в неробочому стані. Сонячні колектори 1 і сонячні батареї 2 знаходяться в складеному стані на платформі 6. Для переведення АВТТ в робочий стан здійснюється підйом сонячних батарей 2 і сонячних колекторів 1 на необхідний кут нахилу за допомогою регульованого кріплення 10. Одночасно проводиться висування опорної рами 7 за межі платформи 6. Положення рами 7 фіксується спеціальної опорою 8.

Надалі підключаються системи підведення тепла 1 і електричної енергії 2 до АВТТ 3 і системи автоматики 4 через перетворювач постійного струму в змінний 5 .

Виробляється запуск АВТТ 3 для зниження температури атмосферного повітря нижче точки роси з відведенням отриманого конденсату для систем життєзабезпечення.

У польових умовах холодне осушене повітря після повітроохолоджувача АВТТ може використовуватися для кондиціювання повітря наметів і бліндажів в жарку пору року.

\section{5. Висновки}

1. Показано, що система отримання води з атмосферного повітря 3 джерелом тепла від сонячних колекторів і з АВТТ з підтискаючим бустеркомпресором перед конденсатором, може бути працездатною 3 джерелами тепла від $85^{\circ} \mathrm{C}$, незважаючи на додаткові витрати енергії на привід бустер-компресора. Порівняльний аналіз енергетичних витрат на стиснення пари робочого тіла в ABTT 3 підтискаючим бустер-компресором і в ПКТТ показав перевагу АВТТ, як при експлуатації в помірному кліматі (в $1,16 \ldots 1,51$ рази при тиску в генераторі 0,6 МПа до 3, $31 \ldots$ 4,33 рази при тиску в генераторі 1,0 МПа), так і тропічному (в $1,13 \ldots 1,48$ при тиску в генераторі 0,6 МПа до $2,42 \ldots$
3,18 при тиску в генераторі 1, 0 МПа).

2. Максимальна енергетична ефективність ABTT в розглянутому діапазоні параметрів досягається при тиску генерації 1,0 МПа, що в умовах помірного клімату відповідає масової частці «міцного» ВАР: 0,57 (температура випаровування $5{ }^{\circ} \mathrm{C}$ ); 0,51 (температура випаровування $0{ }^{\circ} \mathrm{C}$ ); 0,48 (температура випаровування мінус $5^{\circ} \mathrm{C}$ ).

3. 3 підвищенням температури в випарнику від $-5{ }^{\circ} \mathrm{C}$ до $+5{ }^{\circ} \mathrm{C}$ у всіх випадках знижується $\mathrm{i}$ електрична потужність циркуляційного насоса, хоча в розглянутому діапазоні параметрів максимальні чисельні значення цієї потужності не перевищують 2,5\% від потужності бустер-компресора ABTT.

4. Найбільш енергоефективним $є$ режим роботи АВТТ 3 температурою в випарнику $5{ }^{\circ} \mathrm{C}$. У цьому випадку має місце і мінімальна кратність циркуляції ВАР, що знижує витрату робочого тіла i, відповідно, теплове навантаження генератора та спрощує рішення задачі охолодження абсорбера.

5. Для інженерних рішень при тиску в генераторі АВТТ 1,0 МПа відмінність між чисельними значеннями зони дегазації в розглянутому діапазоні температур навколишнього середовища, кипіння і випаровування несуттєво.

6. Застосування технології нічного радіаційного випромінювання в СПВ дозволить створити запас природного холоду для додаткового охолодження конденсаторів термотрансформаторів тепла різних типів на протязі всього періоду роботи [30].

7. Практично у всіх розглянутих кліматичних зонах 3 дефіцитом водних ресурсів процес отримання води 3 атмосферного повітря найбільш енергетично витратний в зимовий період року, а найбільш енергоефективний - в літній.

8. У літній період року питомі енерговитрати чисельно однакові при зміні кінцевої температури в процесі охолодження від 5 до $15{ }^{\circ} \mathrm{C}$, що дозволить організувати енергозберігаючий процес роботи термотрансформаторів тепла різного типу за рахунок підвищення температури кипіння у випарнику.

9. Розроблено варіант системи отримання води в транспортному виконанні, яка призначена для роботи в польових умовах в автономному режимі.

\section{Література}

1. Міжнародне десятиріччя дій «Вода для життя», 2005-2015 роки. Механізм «ООН - водні ресурси. 
- Режим доступу: URL: http://www.un.org/ ru/water forlifedecade/unwater.shtml.

2. Аль Майте Валід Абдулвахід Мохаммед, Фрумін Г.Т. Напрямки вдосконалення водозабезпечення в країнах Аравійського півострова // Сучасні проблеми науки та освіти. - 2007. - №6 C. 13-17.

3. Аль Майте Валід Абдулвахід Мохаммед, Фрумін Г.Т. Екологічно безпечні технології водозабезпечення в країнах Аравійського півострова // Сучасні проблеми науки та освіти. - 2008. - №3 C. 111-115.

4. Осадчук Є.О., Тітлов О.С., Мазуренко С.Ю. Визначення енергоефективних режимів роботи абсорбційної водоаміачної холодильної машини в системах отримання води 3 атмосферного повітря // Холодильна техніка та технологія. - 2014. - № 4. - C. 54-57.

5. Іщенко І.М., Тітлов О.С., Краснопольський А.Н.. Перспективи застосування абсорбційних водоаміачних холодильних машин в системах отримання води 3 атмосферного повітря // Збірник наукових праць Вінницького національного аграрного університету. Серія: Технічні науки. - Вип. 7. - 2011. - C.92-97.

6. Шелепов В.А., Мелкозеров М.Г. Отримання води з атмосферного повітря за допомогою різних холодильних машин // Актуальні проблеми авіації і космонавтики. Технічні науки. Видавництво: Сибірський державний аерокосмічний університет ім. акад. М.Ф. Решетнева (Красноярськ). - 2012. №8. - C.74-75.

7. Василів О.Б., Коваленко О.О. Структура та шляхи раціонального використання води на харчових підприємствах // Наукові праці. - 2009. Вип. 35. - Т. 1. - С. 54-58.

8. The european solar thermal industry federation (ESTIF) -Режим доступу: URL : http://www.estif.org. 9. Thermal solar line // Rotartica, air conditioning appliances: - Solar Line, single effect 4,5 kW. - Peжим доступу: URL: http://www.rotartica.com.

10. SorTech. Innovative Cooling. - Режим доступу: URL: http://www.sortech.de/en/trade/solare-kuehlung.

11. Henning H.-M., Rainer B., Lokurlu A., Noeres P. Solare Kuhlung und Klimatisierung-Beluftung und Warmeruckgewinnung // Solare Kuhlung und Klimatisierung. - Themen, 2005. - P. 45-54.

12. Solar Cooling. - Режим доступу: URL: http://www.solid.at/en/references/solar-cooling.

13. Дорошенко О.В., Гончаренко В.О. Розробка багатофункціональних сонячних систем на основі тепловикористовуючого абсорбційного циклу і тепломасообмінних апаратів з рухомою насадкою // Холодильна техніка та технологія. - 2015. - № 1. С. 35-46.

14. SolarFrost: The Icebook. - Режим доступу: URL: http://www.solarfrost.com/en/icebook.html.

15. Jakob U., Schneider D., Eicker U. Raumklimatisierung mittels solar betriebener DiffusionAbsorptions kaltemaschine // Horizonte 26. - 2005. P. 10-14.

16. Татауров О. Холод - Сонце. Для винахідників та інженерів холодильна техніка на альтернативних джерелах енергії - найбагатше поле для творчості // Холодильний бізнес. - 2009. - №7 C. $18-20$.

17. Zohar A., Jelinek M., Levy A., Borde I. The influence of diffusion absorption refrigeration cycle configuration on the performance // Applied Thermal Engineering. - 2007. - №. 27. - P. 2213-2219.

18. Sozen A., Menlik T., Ozbas E. The effect of ejector on the performance of diffusion absorption refrigeration systems: An experimental study // Applied Thermal Engineering. - 2012. - №. 33-34. P. 44-53.

19. Осадчук Є.О., Тітлов О.С. Пошук енергоефективних теплових режимів водоаміачної абсорбційної холодильної машини в широкому діапазоні експлуатаційних параметрів //Харчова наука і технологія. - 2012. - № 4. - С.79-82.

20. Тітлов О.С. Науково-технічні основи енергозбереження при проектуванні холодильних апаратів 3 абсорбційної-дифузійними холодильними машинами // Наукові праці. - 2006. - № 29. - Т. 1. - C. 194-200.

21. Бараненко А.В., Бєлозьоров Г.А., Таганцев О.М., Смислов В.І., Бондарєв В.Н. Стан і перспективи розвитку холодильної галузі в Росії // Холодильна техніка. - 2009. - № 3. - С. 20-24.

22. Василів О.Б., Тітлов О.С., Осадчук Є.О., Кузаконь В.М. Патент на винахід № 114658 Україна, МПК Е03В 3/28, F25B 15/10, F25D 21/14 (2006.01) Спосіб одержання води з атмосферного повітря та установка для його здійснення. - № а 2015 06905; заявл. 13.07.2015; опубл. 10.07.2017, Бюл. № 13.

23. Titlov O., Baidak Yu., Khmelnyuk M. Optimizing $\mathrm{NH}_{3}-\mathrm{H}_{2} \mathrm{O}$ absorption system to produce water from ambient air // Applied Science Report (ASR). 2015. - V. 10. - No 2. - P.91-100.

24. Морозюк Т.В. Теорія холодильних машин i теплових насосів: монографія. - Одеса: Студія «Негоціант», 2006. - 712 c. 
25. Галімова Л.І. Абсорбційні холодильні машини і теплові насоси. - Астрахань: вид-во Астраханського технічного університету, 1997. - 226 с. 26. Цой А.П., Грановський О.С., Цой Д.А., Бараненко А.В. Вплив клімату на роботу холодильної системи, що використовує ефективне випромінювання в космічний простір // Холодильна техніка. - 2014. - № 12. - С. 36-41.

27. Prommajak T., Phonruksa J., Pramuang S. Passive cooling of air at night by the nocturnal radiation in Loei, Thailand // International journal of renewable energy. - 2008. - Vol. 3. - №1. - P. 33-40.
28. Погода в 243 країнах світу. Розклад погоди. Режим доступу: URL:https://rp5.ru.

29. Богданов С. Н. та ін. Довідник. Властивості речовин. Холодильна техніка. - СПб.: СПбГАХПТ, 1999. - $320 \mathrm{c}$.

30. Тітлов О.С., Цой А.П., Алімкешова А.Х., Джамашева Р. А. Розробка систем охолодження 3 використанням ефекту нічного випромінювання // Scientific journal «ScienceRise». - 2019. - № 12 (65). - C. 24-33.

Отримана в редакції 16.11.2020, прийнята до друку 08.12.2020

\title{
Search for energy efficient modes of systems operation for obtaining water from atmospheric air on the basis of absorption water-ammonia thermal transformers of heat and solar collectors
}

\author{
Ye. Osadchuk ${ }^{1}$, O. Titlov ${ }^{\varpi^{2}}$ \\ ${ }^{1,2}$ Odessa National Academy of Food Technologies, 1/3 Dvoryanskaya str., Odessa, 65082, Ukraine \\ $\triangle$ e-mail: ${ }^{1}$ osadchuk1980@gmail.com; ${ }^{2}$ titlov1959@gmail.com \\ ORCID: ${ }^{1}$ http://orcid.org/0000-0002-8955-2041; ${ }^{2}$ https://orcid.org/0000-0003-1908-5713
}

\begin{abstract}
It is shown that a system for obtaining water from atmospheric air with a heat source from solar collectors and with an automatic heat exchanger with a booster compressor in front of the condenser, can be operable with heat sources from $85^{\circ} \mathrm{C}$. Comparative analysis of the energy consumption for the compression of steam of the working fluid in the absorption water-ammonia thermal heat transformer (AWTT) with a booster compressor and in the vapor compression thermal heat transformer showed the advantage of the AWTT, as in operation in a temperate and tropical climate. The calculations of the maximum energy efficiency of AWTT, which in the considered range of parameters is achieved at a generation pressure of 1,0 MPa, and in temperate climates depends on the mass fraction of "strong" water-ammonia solution (WAS) and evaporation temperature. The most energetically efficient mode of operation is the AWTT with a temperature in the evaporator of $5{ }^{\circ} \mathrm{C}$. In this case, there is also a minimum multiplicity of water-ammonia solution circulation, which reduces the flow rate of the working fluid and, accordingly, the thermal load of the generator and simplifies the solution of the problem of cooling the absorber. Practically in all considered climatic zones with water scarcity, the process of obtaining water from atmospheric air is most energetically expended in the winter period of the year, and the most energetically efficient - in the summer period. In the summer period of the year, the specific energy consumption is numerically comparable when the final temperature changes during the cooling process from $5{ }^{\circ} \mathrm{C}$ to $15^{\circ} \mathrm{C}$. It will allow organizing an energy-saving process of operation of heat transformers of various types by increasing the boiling point in the evaporator. A transport version of the water production system has been developed, designed to work in the field in an autonomous mode.
\end{abstract}

Keywords: Absorption water-ammonia thermal heat transformer; Water-ammonia solution; Solar collectors; Water production system; Energy efficiency

\section{References}

1. International decade for action "Water for Life", 2005-2015. Mechanism "UN - water resources". Ac- cess mode: URL: http://www.un.org/ru/waterforlifede cade/unwater.shtml.

2. Al Maitami Walid Abdulwahid Mohammed, Frumin, G.T. (2007) Directions for improving water 
supply in the countries of the Arabian Peninsula. Modern problems of science and education, 6, 13-17.

3. Al Maitami Walid Abdulwahid Mohammed, Frumin, G.T. (2008). Environmentally safe water supply technologies in the countries of the Arabian Peninsula. Modern problems of science and education, 3, 111-115.

4. Osadchuk, Ye.O., Titlov, O.S., Mazurenko, S.Yu. (2014) The designation of energy efficient operation modes of absorption water-ammonia refrigeration machine in systems for removing water from atmospheric air. Refrigeration engineering and technology, 4, 54-57.

5. Ishchenko, I.N., Titlov, O.S., Krasnopolsky, A.N. (2011) Prospects for the use of water-ammonia absorption refrigeration machines in systems for obtaining water from atmospheric air. Collection of science practitioners of the Vinnytsia national agrarian university. Series: Technical Sciences, 7, 92-97.

6. Shelepov, V.A., Melkozerov, M.G. (2012) Obtaining water from atmospheric air using various refrigeration machines. Actual problems of aviation and cosmonautics. Technical science. Publisher: Siberian state aerospace university named after M.F. Reshetnev (Krasnoyarsk), 8, 74-75.

7. Vasiliv, O.B., Kovalenko, O.O. (2009) Structure and ways of rational use of water at food enterprises. Scientific works, 35(1), 54-58.

8. The european solar thermal industry federation (ESTIF). Access mode: URL: http://www.estif.org.

9. Thermal solar line. Rotartica, air conditioning appliances: Solar Line, single effect 4,5 kW. Access mode: URL: http://www.rotartica.com.

10. SorTech. Innovative Cooling. Access mode: URL: http://www.sortech.de/en/trade/solare-kuehlung.

11. Henning, H.-M., Rainer, B., Lokurlu, A., Noeres, P. (2005) Solare Kuhlung und KlimatisierungBeluftung und Warmeruckgewinnung. Solare Kuhlung und Klimatisierung. Themen, 45-54.

12. Solar Cooling. Access mode: URL: http://www. solid.at/en/ references/solar-cooling.

13. Doroshenko, O.V., Goncharenko, V.O. (2015) Development of multifunctional solar systems based on heat-using absorption cycle and heat-mass exchangers with a movable nozzle. Refrigeration engineering and technology, 1, 35-46.

14. SolarFrost: The Icebook. Access mode: URL: http://www.solarfrost.com/en/icebook.html.

15. Jakob, U., Schneider, D., Eicker, U. (2005) Raumklimatisierung mittels solar betriebener Diffusion-Absorptions kaltemaschine. Horizonte 26, 10-14.
16. Tataurov ,O. (2009) Cold - the Sun. For inventors and engineers, refrigeration equipment on alternative energy sources is the richest field for creativity. Refrigeration business, 7, 18-20.

17. Zohar, A., Jelinek, M., Levy, A., Borde, I. (2007) The influence of diffusion absorption refrigeration cycle configuration on the performance. Applied thermal engineering, 27, 2213-2219.

18. Sozen, A., Menlik, T., Ozbas, E. (2012) The effect of ejector on the performance of diffusion absorption refrigeration systems: An experimental study. Applied thermal engineering, 33-34, 44-53.

19. Osadchuk, Ye.O., Titlov, O.S. (2012) Search for energy-efficient thermal regimes of water-ammonia absorption refrigeration machine in a wide range of operational parameters. Food science and technology, 4, 79-82.

20. Titlov, O.S. (2006) Scientific and technical bases of energy saving in the design of refrigeration units with absorption-diffusion refrigeration machines. Scientific papers, 29, 1, 194-200.

21. Baranenko, A.V., Belozyorov, G.A., Tagantsev, O.M., Smyslov, V.I., Bondarev, V.N. (2009) State and prospects of the refrigeration industry in Russia. Refrigeration technique, 3, 20-24.

22. Vasyliv, O.B., Titlov, O.S., Osadchuk, Ye.O., Kuzakon, V.M. (2015) Patent for invention № 114658 Ukraine, IPC E03B 3/28, F25B 15/10, F25D 21/14 (2006.01) Method of obtaining water from atmospheric air and installation for its implementation. № a 2015 06905; declared 13.07.2015; publ. 10.07.2017, Bull. № 13 .

23. Titlov, O., Baidak, Yu., Khmelnyuk, M. (2015) Optimizing $\mathrm{NH}_{3}-\mathrm{H}_{2} \mathrm{O}$ absorption system to produce water from ambient air. Applied science report (ASR), 10(2), 91-100.

24. Morozyuk, T.V. (2006) Theory of refrigeration machines and heat pumps: a monograph. Odessa: Studio "Negotsiant", 712.

25. Galimova, L.I. (1997) Absorption refrigeration machines and heat pumps. Astrakhan: published by Astrakhan Technical University, 226.

26. Tsoy, A.P., Granovsky, O.S., Tsoy, D.A., Baranenko, A.V. (2014) The influence of climate on the operation of a refrigeration system that uses effective radiation in space. Refrigeration technique, 12, 36-41. 27. Prommajak, T., Phonruksa, J., Pramuang, S. (2008) Passive cooling of air at night by the nocturnal radiation in Loei, Thailand. International journal of renewable energy, 3(1), 33-40.

28 . Weather in 243 countries. Weather schedule. Ac- 
cess mode: URL: https: //rp5.ru.

29. Bogdanov, S.N. et al. (1999) Directory. Properties of substances. Refrigeration equipment. St. Petersburg: SPbGAKhPT, 320.

30. Titlov, O.S., Tsoy, A.P., Alimkeshova, A.Kh., Jamasheva, R.A. (2019) Development of cooling systems using the effect of night radiation. Scientific journal "ScienceRise", 12 (65), 24-33.

Received 16 November 2020 Approved 08 December 2020

Available in Internet 11 January 2021 